\title{
1. Introduction: how to bring the silos together
}

We do live in contentious times. During recent decades US society has been pulled apart to the extent that any sense of commonality has been greatly diminished, and public discussion has broken down into an exchange of tirades. Gone are Republican senators such as Charles Percy, Edward Brooke, and Jacob Javits, and Democrats such as Mike Mansfield, Robert Byrd, and Sam Ervin, as well as their counterparts in the House, who would engage in cross-party discussion and the creation of policy that sought to enhance the well-being of the citizenry rather than division-enhancing actions that promoted narrow party interests. But, this was back in the 1970s, give or take a few years on either side. The movement away from cross-aisle cooperation was greatly stimulated by the actions of the Republican Speaker of the House, Rep. Newt Gingrich, during the 1990s, when he pressed for measures that diminished the efficacy of the democratic processes and promoted political polarization. Gingrich was followed a decade later by the right-wing Tea Party, formed in response to the stimulus package put forth by President Obama. Neither political party is blameless in this destruction of comity, but it is the Republicans who have gradually destroyed their own party and replaced it with a Trumpist self-centered political structure, of which the former president, Donald Trump, is the commanding figure. Beyond self-serving policy, this new Trumpist movement has most recently refused to accept the results of the 2020 presidential election and lodged groundless charges that the electoral system is corrupt - 90 federal and state judges rejected approximately 60 Trump challenges to election results that had been lodged in courts, and only two or three inconsequential challenges were successful. Ultimately, the movement mounted an attack on the US Capitol that shocked almost the entire country and led to President Trump's second impeachment.

Anne Applebaum's analysis captures this development in US political life very well. In Twilight of Democracy, she depicts the rise of authoritarianism in Hungary, in the Brexit movement in the UK, and in Trump's America. The procedure is that of attacking: 1) the press, so as to delegitimize it; 2) the judiciary, so as to convert it from a watchdog to a house pet; and 3) the legislative bodies, so as to gain control of them. Former president Trump applied all three of these anti-democracy strategies. As Appelbaum points out, "Given the right 
conditions, any society can turn against democracy." This both calls into question and destroys democratic political processes, and even democracy itself. Those who are of an authoritarian disposition prefer homogeneity and order, while those who support democracy are comfortable with diversity and difference (Applebaum 2020, pp. 15 and 17). In the Trumpist US, this has shown up powerfully in positions taken with regard to the following public policy areas:

- Immigration - While he was president, Donald Trump denigrated Central American migrants, referring to them as gang members, diseased, rapists, free-loaders, and people who would take jobs from Americans, despite all evidence pointing to the reverse. He also introduced a ban on immigration by Muslims, on the basis that they are all terrorists and religious fanatics who cannot conform to American values and ideals, again with no evidence to support this.

- Social benefits for lower-income people - The Trump movement attempted to remove the Affordable Care Act which brought a variety of health benefits to lower-income people who cannot afford costly private healthcare. No alternative has been designed or offered as a replacement. Of equal consequence, funding for public schools was diverted to private schools for the wealthy by Secretary of Education Betsy DeVos.

- Individuals who are not of the dominant race, religion, sexual orientation, and ideology - Former President Trump gave his support to white supremacist nationalists and other right-wing cult members, he exacerbated the attacks on the Black community, he suddenly manifested a strong adherence to Christianity to gain support for the evangelical movement, and did little to assist the LGBTQ+ community. Black female Vice President Kamala Harris has been referred to by the Christian right as a "Jezebel", a term with heavily sexist connotations.

- Taxation, expenditure, and budgetary policy - The major tax policy of the Trump administration was a very substantial tax reduction for higher-income individuals and corporations. Once this was accomplished, any other suggestions for tax reductions that would benefit lower-income individuals and small businesses were met with impassioned pleas to respect the need to avoid increasing the national debt or the budget deficit.

- The functioning of democratic processes - Former President Trump's refusal to admit that he lost the 2020 presidential contest and his ongoing unsubstantiated claims of voter fraud work to diminish the attachment of his supporters to the US's democratic processes. His supporters in elected positions and his legal assistants have pursued frivolous challenges to the electoral system, knowing full well that these steps have no merit and serve merely to enflame his supporters among the electorate. Finally, his supporters mounted the attack on the Capitol. 
- Promotion of political divisiveness - The recent rather decisive victory of Joe Biden in the presidential election (when Donald Trump received the same number of electoral college votes - 306 - as Joe Biden, he referred to it as a landslide) gives clear indication that this is not the dominant sentiment in the US; however, the events of the Biden administration will reveal how lasting the strength of the Trumpist movement will be over time. President Biden gives every indication that he wants to restore a more congenial political environment in Washington.

The future of the Republican Party is now an issue for public discussion - is a third party possible? Will traditional Republicans leave the party, perhaps to become Independents, or will they just quietly hold their place, desperately hoping to hold off a Trumpist challenge in the next primary election? Has the GOP (Grand Old Party) become the PoT (Party of Trump)?

The relevance of this to the current discussion is confirmed by Jeff Lewis's analysis of the movement in the Senate and the House toward conservative and liberal positions between 2000 and 2020. Using data on political stance among the main parties over time, he demonstrates that average (mean) liberal-conservative sentiment in the Senate has moved to the right among Republicans, from 34 to 50 per cent, and to the left among Democrats, from 29 to 33 per cent (where zero indicates a centrist viewpoint). In the House, conservative sentiment has shifted from 40 to 51 per cent among Republicans, while liberal sentiment has remained unchanged at 37 per cent (Lewis 2020). Examining liberal-conservative partisan polarization by chamber, he shows that the percentage movement toward conservativism has been 47 per cent in the Senate and 14 per cent in the House, while the movement toward liberalism has been 28 per cent in the Senate and 0 per cent in the House. This much more powerful hardening of stance towards the right amongst Republicans points to the conclusion that it is conservative sentiment that has been the active force in the growing dysfunctionality of Congress between the years 2000 and 2020.

This polarization is also highlighted by Daniel Cox, in a study for the American Enterprise Institute, published in February 2021, presenting data collected after the attack on the Capitol. Cox found that 98 per cent of Democrats and 73 per cent of Independents believe President Biden's election victory was legitimate, but this is true for only 32 per cent of Republicans. Thirty per cent of Republicans believe that Donald Trump has been fighting against a "group of child sex traffickers that include prominent Democrats and Hollywood elites", as promoted by the far right QAnon conspiracy group (Cox 2021, p. 6). Seventy-nine per cent of Republicans, and 27 per cent of Democrats, believe that the system is stacked against conservatives and people with traditional values, and, shockingly, 55 per cent of Republicans are in favor of using force as a way to stop the decline in the American way of life. Finally, while the 
percentage of Americans describing themselves as "extremely proud" to be an American declined from 58 to 51 per cent during the eight years of President Obama's administration, during the four years of the President Trump administration this figure declined from 51 to 32 per cent - one per cent per year with Obama and five per cent per year with Trump. In the three years following $9 / 11$, the figure hovered within one point of 70 per cent.

In the next chapter we will try to ascertain where these politically distinctive groups of Americans live - in what regions, in cities or towns, in urban or rural places, in Blue states or in Red states, and so forth.

\section{POLICY AREAS}

In the chapters that follow we will examine how US society can approach policies that will unite the citizenry across a wide array of populations, regions, classes, incomes, and political preferences in six key policy areas. Some policy issues, such as the budget, taxation, regulation and international trade easily get deep in the weeds of theory and legislative procedures. Engaging the larger public on such issues can be difficult, as they may appear boring to many people. However, the following six policy issues are accessible to the broader public and, when presented compellingly, can be the subject of popular discussion: 1) drugs, alcohol and suicide; 2) schooling; 3) the economy; 4) infrastructure; 5) the environment; and 6) urban and regional issues. These are the policy areas that divide us as a society, and on which the electorate can, and does, have opinions. But beyond these opinions are analyses that can enable us to extract, from the information we have about them, ways in which these issues affect specific constituencies of the population. Once we know how individuals in different situations are impacted by these aspects of our lives, we can then isolate some of the elements so as to form cross-group constituencies to support policies that are inclusive and can be mobilized to exert influence on Congress.

Drugs, alcohol and suicide (Chapter 3) have been discussed compellingly by Anne Case and Angus Deaton in their book, Deaths of Despair (2020). One of the principal findings is that these personal tragedies are not confined to any sector of society but are pervasive in their incidence. However, in contrast with the drug and alcohol situation in the US in the 1970s and 1980s, which was significantly centered in minority populations in the disadvantaged districts of the nation's cities, the contemporary scene is dominated by lower income, rural, white individuals. This latter population suffers disproportionately from the scourges of Case and Deaton's three diseases of despair. An important element in the rise in opioid abuse is the rather predatory activities of organizations such as Purdue Pharma and other Big Pharma companies; the individuals 
behind them, such as the Sackler family; and the companies, such as Walmart and Walgreen, that aggressively market opioids and thus promote drug abuse.

Schooling (Chapter 4) ranges from pre-kindergarten through K-12 (kindergarten to 12 th grade), and extends to post-secondary education, that is, to vocational schooling and apprenticeship programs, and to colleges and universities. The schooling a young person receives is the key to the rest of his/ her life. As Robert Putnam wrote, contrasting the post-WWII years with the current situation, "public education and community support for kids from all backgrounds managed to boost a significant number of people up the ladder. ... Those supportive institutions, public and private, no longer serve poorer kids so well" (Putnam 2015, p. 229). In addition to pre-kindergarten, it is necessary to offer free daycare so that women do not have to give several years of their lives to childcare but can find employment, for personal gratification as well as for income.

Economic issues (Chapter 5) relate to the adequacy of incomes for all members of society. Recent discussion has focused on the need for a minimum wage that will enable workers to enjoy acceptable standards of living, and attention is being given to lifetime earnings and income security. In addition, small businesses need supportive policies and access to capital and other funding. The failure of small businesses, of course, leads to increased unemployment and income loss by working-class people. Joseph Stiglitz, among others, has identified the costs of this: "Widely unequal societies do not function efficiently and their economies are neither stable nor sustainable in the long term" (2012, p. 83). Access to jobs must be increased for both women and minorities. Finally, the economy of the land must be dealt with - how can family farms and other land-based economic activities be maintained? This is the heart of rural America and vast areas of land.

Infrastructure (Chapter 6) can be broadly inclusive, but here we focus on: 1) roads and access to clean water and waste disposal, and 2) high speed internet connectivity throughout the land. Around the world, many cities, such as Paris and Barcelona, are rethinking the use of cars, bicycles, pedestrian ways and parks in their city centers. In the US, Portland, Oregon, has been doing this for 20 years. The pandemic has forced all cities, large and small, to rethink their schools, shopping malls, municipal services, and small shops - all of which rely on access to high-speed internet connectivity. Many workers are now spending their working days at home, with only an occasional visit to the office. This is having a transformative impact on many city centers and their dining, retail, and cultural facilities. The central issue in this book is the tension between the city and the country, urban and rural. With telecommuting increasingly common, many smaller cities and towns are gaining population as workers leave the large cities. 
Environmental issues (Chapter 7) include the need to ensure access to clean air and water, but policies are also needed to ameliorate the negative consequences of global warming and its impacts on weather, causing natural disasters, such as flooding and forest fires, which affect all residents. Failure to deal adequately with these issues will bring enormous costs in the long-term, from the construction of ultimately futile dikes, retaining walls, and floodwater infrastructure, to the forced relocation of residences and even towns. These latter costs will be borne by those affected, unless other arrangements are put in place.

Urban and rural development (Chapter 8) raises issues such as how we can get cities and towns, urban and rural areas to participate in policy discussions that will bring benefits to all parties, instead of battling it out in a zero-sum game between different locations. Telecommuting has been linking many smaller and larger cities in a complex restructuring of the work space. Regional policies will bring cities and towns together in cooperative ventures. Organizations such as the US Conference of Mayors and, especially, the National League of Cities can focus their initiatives in ways that will facilitate progress, once progress has been defined. Focusing on basic city or town amenities will enable urban centers to enhance their competitiveness vis-à-vis other municipalities.

These are six policy areas that we must deal with effectively if deterioration in our society is to be avoided. The divisive public discussion to date has used these policy issues to compartmentalize our society into silos between which a rational discourse has become virtually impossible. The performance of the Senate under the leadership of Majority Leader Mitch McConnell is a prime case in point. After gaining the Senate majority in 2012, Sen. McConnell stymied any effort by the Obama administration to implement recommendations in virtually every area of public policy. The collegiality of the pre-1990s Senate had been destroyed, and in its place were two silos. The events at the end of the Trump administration make it clear that this "across-the-aisle" enmity has not diminished. Resolving this remains a primary task for the Biden administration.

\section{DESCRIPTIVE CATEGORIES}

Central to what follows is the issue of whether the notion of silos is pervasive throughout society or is concentrated principally in political discourse and actions. Individuals can be placed in descriptive categories without them being isolated from others, or they can, with pride or displeasure, self-identify in opposition to others. There are five ways in which we have been differentiated as a consequence of the impacts of the policy areas we have just examined, and these differentiations provide the definition of the silos in which we have 
clustered. They are 1) urban or rural, 2) age, 3) education or skill level, 4) income, and 5) gender. The category that has been most contentious of the five, and is central to this book, is urban or rural. This has specificities that relate to population density, quality of life, the nature of the economic base, population age distribution, access to high-speed internet, access to a major airport with international connections, and cultural and educational institutions. Rural areas have been designated "fly-over zones", since many urban dwellers, who used to enjoy driving a car across the country so as to get to know it and to experience its beauty and pleasures, now simply fly from one big city airport to another. The ignorance of the other by both urban and rural populations contributes to the creation of the silos into which so many of us have retreated.

Age is a category that has gotten a great deal of attention since we began to categorize individuals as generation Z (born 1997-2012), millennials (1981-1996) generation X (1965-1980), baby boomers (1946-1964) or seniors. Each has its own story, so to speak; for example, many millennials were teenagers during the Bush economic collapse, experienced the Obama years, and then, as they entered the workforce, were hit by the pandemic and Trump, economic collapse, and the terrible situation for new labor-force entrants. Generation $\mathrm{Z}$ is seen as more liberal, accepting of sexual identity differences, and involved in political movements, although they too have entered the workforce in a deep recession. Each of these two generations can look forward to lower lifetime earnings, among other things, due to their experiences during their first few formative years in the workplace. The other "generations" can be similarly depicted. The pressing question is, then, how will they each relate to political polarization and to Trumpist attacks on democratic institutions and processes?

Education or skill level attained is a powerful differentiator among all groupings of individuals. In fact, Case and Deaton consider this, and access to healthcare, as the most powerful determining factor "not only in death but also in quality of life" (2020, p. 3) It is a factor that can generate feelings of participation or of exclusion, depending on the perceived status of the specific employment position being held. A sense of exclusion can lead individuals to adopt non-standard or disruptive political positions that promise a radical transformation of society that will benefit the dissatisfied worker. Social status is often tied to educational or skill attainment, especially in societies in which apprenticeships, vocational training and technical school attendance do not convey status. In many European countries, skill development is more highly regarded in relation to educational attainment than has been the case in the US.

Income is the fourth category and it goes beyond the question of whether one has a high or a low income. Equally revealing information is gained from a series of additional questions that relate to that income. First, was it obtained through physical labor or through knowledge and education? Second, was it 
obtained through inheritance? Third, was ownership of a business enterprise the source of income? Fourth, was the source of income financial assets or wealth? Fifth, was the income derived from social programs or welfare? These aspects of an individual's income have a significant impact on how people respond to specific policy initiatives and how their lives are is impacted by the policies adopted.

The fifth category is gender and sexuality. The dominant genders are, of course, male and female; however, in recent years individuals have become more willing to identify themselves as one of the LGBTQ identities that have recently become legal, socially acceptable, admired, and accepted in the military, entertainment and corporate worlds. However, the Supreme Court has recently declared that it is legal for a vendor of goods, in this case a gay wedding cake, to decide to withhold a service or product if the purchaser is of a non-heterosexual orientation, for example, gay or lesbian.

The essential question that must be asked with regard to these five categories is: what do the individuals in each of them want from government? What policies do they believe will benefit them or work to their disadvantage? Will they participate in traditional political parties, in the anticipation that this will bring to them, in the long run, an acceptable share of what the government has to offer? Or will they be attracted to fringe parties, or parties of alienation, offering personal, zero-sum gain to the exclusion of others, as demonstrated by Applebaum? If we collectively find comfort in a society of silos, then there is little possibility that we will be able to engage in a fruitful and mutually satisfying discussion of complexes of social and economic policies. The political system will then deteriorate into a battle between silos in an effort to gain political power to force one set of policies on everyone. These five descriptive categories of individuals are differentiated in a number of ways, but the one that is central to this book is the bifurcation of people according to whether they life in a city or a town, in an urban or a rural setting - that is, in a Blue state or a Red state.

\section{THE TREATISE OF THE BOOK}

The treatise of this book is that these policy areas are not confined in silos but, rather, that policies - on drugs, alcohol, and suicide; schooling; economic issues; infrastructure; urban and regional development policy; and the environment - have powerful impacts on some, or many, members of each of the silos into which we have been consigned, or have chosen to consign ourselves. From this recognition can come an understanding that public policy initiatives that treat each of the policy areas - such as schooling, infrastructure and healthcare - with equity are conceivable and can in fact be implemented. Once this has been recognized, we will be able to engage in the destruction of 
silo-to-silo bickering, to tackle the lack of understanding and respect, and can work to create a dialogue based on mutual understanding that is non-zero-sum in nature. Such a dialogue has been sorely missing for the past several decades. Obviously, this is not a project that can be implemented in the short term. The first step is that of understanding what the possible political discussion could be, and then the second step is to work within that framework to develop policies that will be beneficial to both, or to multiple, constituencies. Some hope can be gained from Robert Putnam's recent work, The Upswing, in which he proposes the "I-We-I" model of the twentieth century. At the end of the nineteenth century, our economy was dominated by monopoly, income inequality, polarization, social dislocation, and cultural narcissism - the "I economy and society". Putnam finds that over the next 60 years, as a consequence of events such as the Great Depression and Roosevelt's policies, as well as World War II, the US developed a society that was less inequal, less monopolistic, less polarized, and less "I-oriented". This was the "We economy and society" of 1940-1980. However in the ensuing half-century, under increasing political enmity and polarization, we have regressed to the social and economic characteristics of 1900 and its "I-orientation". He challenges us to "resurrect the earlier communitarian virtues in a way that does not reverse the progress we've made in terms of individual liberties" (2020, p. 341).

In this book we attempt to provide a road map for this journey forward to another "We economy and society".

\section{REFERENCES}

Applebaum, Anne, Twilight of Democracy, New York: Doubleday, 2020.

Case, Anne and Angus Deaton, Deaths of Despair, Princeton: Princeton University Press, 2020.

Cox, Daniel A., "After the Ballots Are Counted: Conspiracies, Political Violence, and American

Exceptionalism", Survey Center on American Life, Washington: American Enterprise Institute, February, 2021.

Lewis, Jeff, "Polarization in Congress", 2020, accessed 22 July 2021 at https:// voteview.com

Putnam, Robert, Our Kids: The American Dream in Crisis, New York: Simon and Schuster, 2015.

Putnam, Robert, with Shaylyn Romney Garrett, The Upswing, New York: Simon and Schuster 2020.

Stiglitz, Joseph, The Price of Inequality, New York: W. W. Norton, 2012. 